\title{
Aina ASKeleEn JÄLJeSSÄ?
}

\author{
- KODIN ULKOPUOLELLE SIJOITETTUJEN LASTEN KOULUTUS JA \\ TYÖLLISYYS JÄÄVÄT KESKIMÄÄRIN MUUTA VÄESTÖÄ \\ MATALAMMAKSI ${ }^{1}$
}

Antti Kääriälä: VTT, erikoistutkija, Terveyden ja byvinvoinnin laitos

antti.kaariala@thl.fi

Janus vol. 29 (3) 2021, 286-291

\begin{abstract}
"Poissaolo on läsnäoloa." - Paavi Pius XIII (Jude Law) tv-sarjassa The Young Pope - piru vai pyhimys
\end{abstract}

The Young Pope - piru vai pyhimys -sarjassa Juden Law:n esittämä Paavi Pius XIII oli kokenut vaikeita lapsuuden kokemuksia. Hänen vanhempansa olivat hylänneet hänet, minkä vuoksi hän oli elänyt lapsuutensa poikakodissa. Mikään ei vaivannut nuorta paavia niin paljon kuin kysymys siitä, miksi vanhemmat ovat poissa ja milloin he palaavat. Vanhemmat olivat läsnä yhä aikuisiällä kaipuuna ja kysymyksinä.

Tarkastelen puheenvuorossa, mitä seurauksia on sillä, että lapsuuteen sisältyy sellaistakin aikaa, jota ei vietetä vanhempien tai muiden huoltajien luona vaan lastensuojelun päättämässä sijoituspaikassa. Keskityn kodin ulkopuolelle sijoitettujen lasten elämänkulkuun pitkällä aikavälillä ja heidän varhaisaikuisuuteensa, joita tarkastelen väestötasoisilla rekisteriaineistoilla.

Väitöskirjani keskeisen tuloksen voi kiteyttää sanoilla: olemme epäonnistuneet. Tämän sanominen on tietysti riski, sillä väitteen voidaan nähdä olevan liian yksinkertainen, liioitteleva ja osoitteleva. Useaan otteeseen olen kuullut toteamukseen, että se, mitä voidaan havaita, on täysin odotettavissa. Silti on voitava sanoa myös, että olem- me epäonnistuneet. Perustelen seuraavaksi, miksi näin on syytä sanoa.

\section{KEITÄ OVAT KODIN ULKOPUOLELLE SIJOITETUT LAPSET?}

Väitöskirjassani (Kääriälä 2020) tutkin lastensuojelusyistä kodin ulkopuolelle sijoitettujen lasten elämänkulkuja. Tällaisia lapsia oli Suomessa vuonna 2019 noin 16000 . Se vastaa noin 1,5 prosenttia lapsiväestöstä (Forsell ym. 2020). Osuus ei kuitenkaan kuvaa ilmiötä koko laajuudessaan. Kun tarkastellaan koko lapsuusaikaa syntymästä 18 vuoden ikään saakka, sijoitettuja lapsia on jopa noin kuusi prosenttia ikäluokasta (Forsell ym. 2018). Kodin ulkopuolelle sijoitettuja lapsia on siis keskimäärin yksi per koululuokka. Kyse on toisin sanoen varsin yleisestä ilmiöstä.

Lastensuojelussa olevista lapsista kodin ulkopuolelle sijoitetut lapset ovat kuitenkin vähemmistö. Tämä johtuu siitä, että suurin osa lastensuojelun piirissä olevista lapsista on lastensuojelun avohuollon asiakkaita. Vuonna 2019 tällaisia lapsia oli kaikkiaan yli 40000 . Lastensuojelun asiakkaiden kokonaisuudessa sijoitettuna olleissa lapsissa kyse on jäävuoren huipusta.

Kodin ulkopuolelle sijoitetut lapset ovat kaikkein haavoittuvimmassa ase- 
massa olevia lapsia yhteiskunnassamme: he ovat lapsia, jotka tarvitsevat lapsista eniten ulkopuolista apua ja tukea. Lastensuojelun sijoituksista yleisimpiä ovat huostaanotot. Muita lastensuojelulain tuntemia tapoja sijoittaa lapsi kodin ulkopuolelle ovat kiireellinen sijoitus ja sijoitus lastensuojelun avohuollon tukitoimenpiteenä. Huostaanotosta lastensuojelulaissa sanotaan, että siihen voidaan ryhtyä, jos kasvuolosuhteiden, huolenpidon puutteiden tai lapsen oman käyttäytymisen takia lapsen terveys tai kehitys on vakavasti vaarantunut. Sijoitusta kodin ulkopuolelle ei tehdä kevyin perustein.

Sijoitetut lapset tulevat perheistä, joissa on keskimäärin merkittävästi enemmän esimerkiksi taloudellisia ongelmia ja suoranaista köyhyyttä, vanhempien mielenterveysongelmia sekä päihdeongelmia (Kestilä ym. 2012). Suuri osa näistä lapsista on tullut kaltoinkohdelluksi, ja heidän tarpeitaan on lyöty laimin. Monet sijoitetuista lapsista ovat erityisen suojelun tarpeessa siksi, että he ovat vaikeuksissa esimerkiksi oman päihteidenkäytön tai rikosten takia tai heidän koulunkäyntivaikeutensa ovat vakavia esimerkiksi poissaolojen vuoksi. (Heino ym. 2016.)

\section{HyvinVOINNIN VARJOPUOLELLA}

Tutkimuskysymyksenäni on, miten sijoitettujen ja ei-sijoitettujen lasten elämänkulku eroaa toisistaan pitkällä aikavälillä. Tutkimuksessani keskityn erityisesti koulutukseen ja työllistymiseen, jotka ovat tärkeitä mittareita sille, miten hyvin nuoret aikuiset pääsevät mukaan yhteiskuntaan.
Tutkimuskohteina ovat Pohjoismaat ja erityisesti Suomi. Kuten tunnettua, pohjoismaiset hyvinvointivaltiot ovat kansainvälisesti merkittävästi monia muita maita edellä hyvinvointiin liittyvien investointien ja palveluiden ansiosta, mikä tekee niistä kiinnostavan tutkimuskontekstin lastensuojelun tutkimuksen kannalta. Pohjoismaissa on vahva pyrkimys siihen, että kaikki lapset lähtökohtiin katsomatta saavat elää hyvää ja turvattua lapsuutta. Enemmistön osalta tämä myös toteutuu. Kun tarkastellaan lastensuojelussa olleiden lasten elämänkulkua, hyvän ja turvatun lapsuuden toteutuminen ei ole kuitenkaan itsestäänselvyys.

Väitöskirjani koostuu neljästä osatutkimuksesta, joiden mukaan sijoitettuna olleilla lapsilla on keskimääräistä matalampi koulutustaso ja heikompi koulumenestys sekä merkittävästi enemmän vaikeuksia työllistymisessä kuin muilla lapsilla. Yhdessä osatutkimuksista vertasimme pohjoismaisten kollegoiden kanssa sijoitettuna olleita nuoria Suomessa, Ruotsissa ja Tanskassa. Havaitsimme, että selvästi yli puolet näistä lapsista on vailla toisen asteen tutkintoa 23 vuoden iässä. Ei-sijoitetuista nuorista tutkinto puuttui kymmenelläkahdellakymmenellä prosentilla. (Kääriälä ym. 2018.) Ero on huomattava.

Koska peruskoulun varaan jääneiden työllisyys on nykyisin heikko, matala koulutustaso tekee sijoitettuna olleiden lasten alkavasta työurasta todennäköisesti paljon keskimääräistä kivisemmän Tästä onkin selviä merkkejä toisessa osatutkimuksessa, jossa tutkimme sijoitettuna olleiden lasten varhaisaikuisuuden koulutus- ja urapolkuja. Koko väestön tasolla polkuja on useita erilai- 
sia, ja pääasiassa ne johtavat koulutuksen kautta työelämään. Yhdellä tutkimuksessa tunnistetuista poluista yhteys koulutuksen ja työn välillä jäi hyvin vähäiseksi. Kyseisellä polulla nuoret elivät suuren osan varhaisaikuisuutta toimeentulotuen ja työttömyyskorvausten varassa. Koko lapsiväestöstä tällaisia nuoria oli noin kaksi prosenttia, mutta sijoitettuna olleista peräti kaksikymmentäviisi prosenttia. (Kääriälä ym. 2019.) Sijoitetuttuna olleet nuoret aikuiset ovat huomattavasti muita todennäköisemmin etäämpänä opinnoista ja töistä. Lisäksi vaikeudet urapolulla olivat monilla varsin pitkäkestoisia.

Kolmannessa osatutkimuksessa tein systemaattisen kirjallisuuskatsauksen aiemmista pohjoismaisista tutkimuksista, jotka käsittelivät kodin ulkopuolelle sijoitettujen lasten varhaisaikuisuuden tilannetta. Tulosten mukaan sijoitettuna olleet lapset kohtasivat muita nuoria merkittävästi useammin mitä erilaisimpia vaikeuksia liittyen esimerkiksi toimeentuloon, koulutukseen, terveyteen tai muihin syrjään jäämisen muotoihin. Kirjallisuuskatsauksen aineistona olevat pohjoismaiset tutkimukset samoin kuin väitöskirjani perustuvat laajoihin koko väestöä kuvaaviin rekisteriaineistoihin, minkä ansiosta näyttö on kattavaa. (Kääriälä \& Hiilamo 2017.)

Vaikka sijoitettuna olleet lapset ovat melko pieni vähemmistö koko väestössä, he ovat kokoaan merkittävästi suurempi joukko niistä, joilla on kaikkein eniten vaikeuksia päästä mukaan yhteiskuntaan aikuisuudessa. Lapsuuden epäonnella on selvästikin pitkät varjot ja ne piirtyvät selvästi esiin, kun verrataan sijoitettuna olleiden nuorten tilannetta muihin nuoriin.
Merkittävä osa vaikeissa oloissa kasvaneista ja lastensuojelun sijoitustoimenpiteiden kohteena olleista lapsista on vaarassa jäädä syrjään keskeisistä yksilöitä kannattelevista instituutioista. Kaikissa Pohjoismaissa on osapuilleen yhtä suuria vaikeuksia onnistua kodin ulkopuolelle sijoitettujen lasten tukemisessa. Hyvinvointivaltio on ollut monella tavalla menestystarina.Väestön hyvinvointi ja koulutustaso ovat korkeammalla tasolla ja terveys parempi nykyisin kuin koskaan aikaisemmin. Ihmiset ovat tutkimusten mukaan maailman onnellisimpia (Helliwell ym. 2020), mikä suomalaisissa skeptikoissa herättää välillä myös epäilyjä. Onko tässä tarinassa kuitenkin aukkoja? Onko lastensuojelun kehitys osa tätä menestystarinaa?

Lastensuojelun yhtenä pääperiaatteena on edistää lapsen etua. Jos kuitenkin olemme aina vain siinä tilanteessa, että suuri osa kodin ulkopuolelle sijoitetuista lapsista jää vaille nykyisin lähes välttämätöntä koulutusta ja pahimmillaan kokonaan koulutuksen ja työelämän ulkopuolelle varhaisaikuisuudessa, on syytä pysähtyä pohtimaan, toteutuuko lapsen etu ihmisoikeussopimuksissa tarkoitetulla tavalla. On syytä miettiä vakavasti, olemmeko rakentaneet yhteiskuntaa, jossa lapsuudessa vaikeuksia kohdanneille ei tunnu löytyvän sijaa. Tämän epäkohdan ratkaisemiseen on syytä paneutua tosissaan.

\section{MIKÄ NEUVOKSI?}

Kertoessani tutkimustuloksistani olen monta kertaa kuullut yleisöstä pohdintaa: "Jos kodin ulkopuolelle sijoittaminen todella johtaa näin huonoihin 
tuloksiin, niin miksi sitä ylipäätään tehdään.” Onko sijoituksesta kodin ulkopuolelle enemmän haittaa kuin hyötyä? Tällaiset kysymykset ovat ymmärrettäviä. Kerrotaanhan lastensuojelusta mediassakin pääasiassa kielteisessä valossa ja epäonnistumisten kautta. Tasaisin väliajoin esiin nousevat uutiset lastensuojelulaitosten epäasiallisista ja laittomista toimintatavoista ovat omiaan ruokkimaan käsitystä.

Väitöskirjaani sisältyvät osatutkimukset eivät kuvaa kodin ulkopuolisten sijoitusten mahdollisia haittoja. Kyse on kuvailevasta tutkimuksesta, enkä ole selvittänyt kodin ulkopuolisen sijoituksen ja myöhemmän elämänkulun välisiä syy-seuraussuhteita, mikä on yleisesti ottaen vaikeaa. On kuitenkin syytä todeta, että tilanteet, joita sijoitetut lapset ennen sijoitusta kohtaavat, ovat usein siinä määrin vakavia, ettei sijoitusta voida jättää toteuttamatta.

Ajattelen, että tutkimustulokseni kertovat ennen kaikkea niistä mittavista haasteista, joita lastensuojelulla on kodin ulkopuolelle sijoitettujen lasten tukemisessa. Keskeinen kysymys on, miten kodin ulkopuoliset sijoitukset voisivat tukea lasten kasvua terveiksi ja hyvinvoiviksi ihmisiksi aiempaa paremmin. Tärkein kysymys on, miten voimme kehittää nykyistä parempaa lastensuojelua ja sijaishuoltoa.

Lapsuuden tilanteen turvaaminen on aivan avainasemassa. On tärkeää kehittää lastensuojelua kokonaisvaltaisesti. Tällä tarkoitan ensinnäkin sitä, että pyritään parantamaan lasten ja perheiden hyvinvointia jo ennen kuin tarve kodin ulkopuoliselle sijoitukselle tulee vastaan. Kodin ulkopuolelle sijoitettu- jen lasten määrä on noussut Suomessa 1990-luvulta 2010-luvulle noin kaksinkertaiseksi. Vuonna 2019 kodin ulkopuolelle oli sijoitettuna enemmän lapsia kuin koskaan aiemmin. Keskeistä on etsiä keinoja tämän kehityksen kääntämiseksi.

Toiseksi on tärkeää kehittää sijaishuoltoa. Väitöskirjani neljännessä osatutkimuksessa havaitsimme, että sijoitettujen lasten koulumenestys peruskoulussa jää muita lapsia selvästi heikommaksi ja että tämä on yhteydessä lasten psykiatrisiin ja neurokehityksellisiin häiriöihin. Tämäkin tulos antaa yhden viitteen siitä, minkälaisiin ongelmiin on syytä puuttua, jos halutaan turvata sijoitetuille lapsille parempi tulevaisuus. Lapsuuden aikainen oireilu, pahoinvointi ja koulunkäynnin vaikeudet ovat keskeisiä syitä sille, miksi sijoitettujen lasten elämänkulut eroavat niin merkittävästi muista. Erityistä huolta on syytä kantaa niistä, jotka tulevat sijoitetuksi kodin ulkopuolelle teini-iässä. Heidän koulumenestyksensä ja työllisyytensä jäivät osatutkimusten mukaan heikommaksi kuin nuoremmalla iällä sijoitetuilla lapsilla.

Kolmas kehityskohde on lastensuojelun jälkihuolto eli ne palvelut, joita tarjotaan sijoitettuna olleille nuorille sijoituksen päättyessä viimeistään 18 vuoden iässä.Vuoden 2020 alussa jälkihuollon ikäraja nousi aiemmasta 21:stä 25 ikävuoteen. Tämän seurauksena Suomessa on ainutlaatuinen mahdollisuus miettiä, miten voisimme paremmin tukea sijaishuollosta itsenäistyviä nuoria. Tutkimustulosteni mukaan jälkihuollon tulisi paremmin tukea nuorten kouluttautumista ja työllistymistä. 


\section{LOPUKSI}

Haluan muistuttaa, että kaikki sijoitetut lapset eivät ole senkaltaisessa vaikeassa tilanteessa, jota puheenvuorossani korostan. Tutkimustulosteni kääntöpuoli on, että liki joka toisella sijoitetuista lapsista on vähintään toisen asteen tutkinto. Niin ikään lähes joka toinen kodin ulkopuolelle sijoitetuista lapsista näyttää olevan varsin vakaalla urapolulla. Tutkimustulokset kuvaavat ennen kaikkea keskimääräisiä eroja sijoitettujen ja muiden lasten välillä. Kun tarkastellaan lapsia yksilöinä, tulokset kertovat myös hyvinvoinnista ja onnistumisista. Pahimmillaan kyse on kuitenkin suurista inhimillisistä menetyksistä, vaikeuksista ja kärsimyksestä.

Väitöskirjani tutkimusaineisto perustuu viranomaisten keräämiin rekisteritietoihin. Tutkimukseni ei sen vuoksi kuvaa sijoitettujen lasten omakohtaisia kokemuksia, jotka voisivat hyvinkin poiketa rekisteritietoihin perustuvan tutkimuksen tuloksista. Siksi tarvitaan myös tutkimuksia, joissa lasten oma ääni kuuluu. Tällaisia tutkimuksia on tehtykin, ja niiden mukaan monilla sijoitetuilla lapsilla on aivan samanlaisia tavoitteita ja toiveita elämältään, koulutukseltaan ja työuraltaan kuin muilla lapsilla. Jotta nämä tavoitteet ja toiveet toteutuisivat aiempaa useampien kodin ulkopuolelle sijoitettujen lasten kohdalla, meidän pitää pystyä tarjoamaan heille paremmat eväät aikuisuuteen ja aivan koko loppuelämään kuin mihin nykyään pystymme.

\section{VIITE}

1 Puheenvuoro on Helsingin yliopistossa 20.8.2020 tarkastetun yhteiskuntapolitiikan väitöskirjan lectio praecursoria.

\section{KIRJALlisuUs}

Forsell, Martta \& Heino, Tarja \& Kuoppala, Tuula (2018) Kodin ulkopuolelle sijoitettujen lasten sijoitusten kestot 2016. Tilastoraportti 9. Helsinki: Terveyden ja hyvinvoinnin laitos. http://urn.fi/ URN:NBN:fi-fe2018042318219 Luettu 16.1.2021.

Forsell, Martta \& Kuoppala, Tuula \& Säkkinen, Salla (2020) Lastensuojelu 2019. Tilastoraportti 28. Helsinki: Terveyden ja hyvinvoinnin laitos. http://urn.fi/ URN:NBN:fi-fe2020070146531 Luettu 16.1.2021.

Heino, Tarja \& Hyry, Sylvia \& Ikäheimo, Salla \& Kuronen, Mikko \& Rajala, Riku (2016) Lasten kodin ulkopuolelle sijoittamisen syyt, taustat, palvelut ja kustannukset: HuosTa-hankkeen (2014-2015) päätulokset. Raportti 3. Helsinki:Terveyden ja hyvinvoinnin laitos. http://urn.fi/ URN:ISBN:978-952-302-644-5 Luettu 16.1.2021.

Helliwell, John F. \& Layard, Richard \& Sachs, Jeffrey D. \& De Neve, Jan-Emmanuel (2020) World Happiness Report 2020. New York: Sustainable Development Solutions Network. https://worldhappiness.report/ Luettu 31.1.2021.

Kestilä, Laura \& Paananen, Reija \& Väisänen, Antti \& Muuri, Anu \& Merikukka, Marko \& Heino, Tarja \& Gissler, Mika (2012) Kodin ulkopuolelle sijoittamisen riskitekijät: Rekisteripohjainen seurantatutkimus Suomessa vuonna 1987 syntyneistä. Yhteiskuntapolitiikka 77 (1), 34-52. http://urn.fi/URN:NBN:fife201209117910 Luettu 16.1.2021.

Kääriälä,Antti (2020) Always a step behind? Educational and employment transitions among children in out-of-home care. Itlan tutkimuksia 1. Helsinki: Itla. http:// urn.fi/URN:ISBN:978-951-51-6396-7 Luettu 16.1.2021.

Kääriälä, Antti \& Berlin, Marie \& Lausten, Mette \& Hiilamo, Heikki \& Ristikari, Tiina (2018) Early school leaving by children in out-of-home care: A comparative study of three Nordic countries. Children and Youth Services Review 93, 186-195. https://doi. org/10.1016/j.childyouth.2018.06.007 Luettu 16.1.2021. 
Kääriälä, Antti \& Haapakorva, Pasi \& Pekkarinen, Elina \& Sund, Reijo (2019) From care to education and work? Education and employment trajectories in early adulthood by children in out-ofhome care. Child Abuse and Neglect 98, 104144. https://doi.org/10.1016/j. chiabu.2019.104144 Luettu 16.1.2021.
Kääriälä, Antti \& Hiilamo, Heikki (2017) Children in out-of-home care as young adults: A systematic review of outcomes in the Nordic countries. Children and Youth Services Review 79 107-114. https://doi.org/10.1016/j.childyouth.2017.05.030 Luettu 16.1.2021. 